\title{
DIDELIO MEISTRIŠKUMO SPORTININKŲ FUNKCINIO PARENGTUMO VERTINIMO PROBLEMA
}

\author{
Jonas Poderys, Eugenijus Trinkūnas, Birutė Miseckaitė, Alfonsas Buliuolis, Albinas Grūnovas
}

Lietuvos kūno kultūros akademija, Kaunas, Lietuva

\begin{abstract}
Jonas Poderys. Profesorius biomedicinos mokslų habilituotas daktaras. Lietuvos kūno kultūros akademijos Kineziologijos laboratorijos vedèjas. Mokslinių tyrimų kryptis - fizinio darbingumo didinimas ir funkcinès būklès kompleksinis vertinimas.
\end{abstract}

\section{SANTRAUKA}

Laikoma, kad organizmas veikia kaip vieninga kompleksine sistema, o funkciniu sistemu reakcija i fizinio krūvio méginius rodo bendrq organizmo būklę ir parengtumq. Visgi iškyla problema, kaip užregistruoti santykiškai nedidelius treniruotumo pokyčius ar skirtumus. Šio tyrimo tikslas — palyginti funkciniu rodikliu, užregistruotu atliekant fizinio krūvio mëginius, vertinimo metodu tiksluma, kai reikia nustatyti santykiškai nedideli sportininku parengtumo skirtuma.

Buvo tiriamos dvi futbolininku grupès: 23 Lietuvos futbolo aukščiausios lygos klubinès komandos sportininkai (FKK), ir 23 Lietuvos futbolo olimpinès rinktinès nariai (LFOR). Tiriamieji atliko tris fizinio krūvio mèginius: Rufjè (lengva, dozuoto aerobinio krūvio), 30 s trukmés vertikaliu šuoliu (maksimalaus anaerobinio krūvio) ir 40 s trukmés tepingo testus. Atliekant krūvius ir atsigavimo metu kompiuterine EKG analizès sistema , Kaunas—krūvis “ buvo registruojama 12 standartiniu EKG derivaciju. Vertinant tyrimu rezultatus buvo naudojami iprastinis euristinis ir kompleksinis rodikliu vertinimas. Tepingo testo rezultatai buvo vertinami pagal Ukrainos küno kultūros universiteto mokslininku parengta CNS funkcinès büklès ir darbingumo rodikliu vertinimo metodika, kuria nustatomi CNS funkcinio paslankumo, nuovargio, bendrojo darbingumo, anaerobinio darbingumo ir anaerobinés talpos rodikliai. Atlikta alometriné tepingo testo rezultatu analizè. Norint ivvertinti, kaip kinta elektrokardiogramos RR ir JT intervalu reikšmès, vertintas adaptacijos greičio rodiklis, nusakantis procentiní JT ir RR pokyčio skirtuma krūvio metu.

Šio tyrimo rezultatai patvirtino hipotezę, kad vertinant didelio meistriškumo sportininku funkcinio parengtumo rezultatus kompleksiškumo metodai, geriau nei euristinis atskiru rodikliu vertinimas, leidžia atskleisti santykiškai nedidelius skirtumus tarp grupiu, galimus individualius sportininko meistriškumo pokyčius, dèl to jie turètu büti daugiau naudojami atliekant sportininku parengtumo tyrimus. Šiı metodu kürimui turi büti skiriama daugiau dèmesio.

Raktažodžiai: fizinio krūvio testai, širdies ir kraujagysliu sistema, centrinè nervu sistema.

\section{IVADAS}

$\mathrm{S}$ portininku treniruotumas apibūdinamas kaip fizinio išsivystymo, fizinio pajègumo, funkciniu gebejimu ir sveikatos visuma. Sportininku treniruotumas - organizmo būklè, gebejjimas pasiekti tam tikrą rezultatą sportinèse varžybose. Treniruotumą geriausiai atskleidžia sportinis rezultatas, o pedagoginiai, fiziologiniai, biologiniai ar psichologiniai testai rodo tik veiks- nius, nuo kurių daugiausia priklauso sportinis rezultatas (Raslanas, Skernevičius, 1998).

Planuojant treniruotes vyksmą, ugdant sportininko fizini pajèguma, gerinant organizmo prisitaikymą prie fizinių krūvių, treneriui būtina žinoti apie sportininko treniruotumo būseną (Raslanas, Skernevičius, 1998; Karoblis, 1999; Poderys ir kt., 2005). Ta informacija gaunama specialiais 
testais, kontroliniais pratimais, funkciniais ir biocheminiais tyrimais (Karoblis, 1999; Poderys ir kt., 2005). Testais ịvertinami fizinio išsivystymo duomenys, fizinio pajègumo, atskiru fiziniu ypatybių lygis, fiziologinių funkcijų gebejjimai, biocheminių tyrimų duomenys, psichomotorinè veikla. Tai rodo bendrą treniruotumą, fizini darbingumą (Raslanas, Skernevičius, 1998; Šiupšinskas, 2004).

Sportininkų darbingumui ir funkcinès būklès pokyčiams vertinti plačiai taikomi fizinio krūvio mėginiai. Organizmo reakcijos į atliekamą krūvị dydis yra vertinamas kaip sportininko funkcinès būklès ar parengtumo rodiklis (Šiupšinskas, 2004). Nors laikoma, kad organizmas veikia kaip vieninga kompleksinè sistema ir funkciniu sistemų reakcijos ị fizinio krūvio mėginius rodo bendrą organizmo funkcinę būklę ir parengtumą, visgi iškyla problema, kaip užregistruoti santykiškai nedidelius treniruotumo pokyčius ar skirtumus. Labai dažnai taikomas iprastas euristinis užregistruotų rodiklių vertinimas neatskleidžia organizmo pokyčių, ypač funkcinių reguliavimo mechanizmų suderinamumo ar jų disharmonijos. Nèra nustatyta struktūrinių ir funkciniu pokyčiu dèl metinio treniruočiu poveikio didelio meistriškumo ir jaunujų sportininkų grupèse. Igijus sportinę formą, labiausiai kinta reguliacinių mechanizmų suderinamumas (Viru A. M., Viru M., 2004). Šio tyrimo tikslas - palyginti funkciniu rodiklių, užregistruotu atliekant fizinio krūvio mėginius, vertinimo metodu tikslumą, kai reikia ìvertinti santykiškai nedidelius sportininku parengtumo skirtumus.

\section{METODIKA}

Tiriamieji. Viena iš sąlygų, keltų pasirenkant tiriamujų kontingenta, ta, kad dvi tiriamuju grupès būtų adaptuotos prie tokio paties kryptingumo fizinių krūvių, o jų meistriškumo skirtumas būtų santykiškai nedidelis. Tik vertinant nedidelius skirtumus galima patikrinti funkcinę būklę, palyginti taikomų vertinimo metodų paveikumą.

Tirtos dvi futbolininkų grupès: 23 Lietuvos futbolo aukščiausios lygos klubinès komandos sportininkai (FKK) ir 23 Lietuvos futbolo olimpinès rinktinès nariai (LFOR). Tyrimai atlikti 2004 m. LKKA Kineziologijos laboratorijoje.

Tyrimo metodai. Sportininkai atliko tris fizinio krūvio mèginius: Rufjè (lengvą, dozuoto aerobinio krūvio mègini), $30 \mathrm{~s}$ trukmès vertikaliu šuolių (maksimalaus anaerobinio krūvio mėginị) ir
$40 \mathrm{~s}$ trukmès tepingo testą. Širdies ir kraujagyslių sistemos ( ̌́KS) funkciniams rodikliams registruoti atliekant krūvius ir atsigavimo metu naudota kompiuterinè EKG analizès sistema „Kaunas—krūvis“. Registruota 12 standartinių EKG derivacijų, vertintas ŠSD, elektrokardiogramos JT intervalo, JT ir RR intervalų santykio (JT / RR), rodikliu grižimo i pradinị lygi pusperiodžių $(1 / 2 \mathrm{~T}$, t. y. matuojamas laikas, per kuri rodiklis grižta iki pusès pokyčio lygio) trukmè.

Statistika ir rezultatų analizès ypatybès. Pateikiami aritmetiniai vidurkiai $(\bar{x})$ ir aritmetinio vidurkio paklaida $(S \bar{x})$. Statistinis skirtumo patikimumas buvo apskaičiuojamas naudojant Studento $t$ testą.

Vertinant tyrimo rezultatus buvo naudojami: iprastinis euristinis (remiantis patirtais reiškiniais, naudojantis analogija ir sinteze), t. y. palygintas registruoto rodiklio pokytis grupèse dèl atlikto fizinio krūvio poveikio, ir kompleksinis rodikliu vertinimas.

Tepingo testo rezultatai buvo vertinami pagal Ukrainos kūno kultūros universiteto mokslininku parengtą CNS funkcinès būklès ir darbingumo rodikliu vertinimo metodiką (Зеленцов, Лобановский, 1998), ivertinant CNS funkcinio paslankumo, nuovargio, bendrojo darbingumo, anaerobinio darbingumo ir anaerobinès talpos rodiklius. Atlikta alometrinè tepingo testo rezultatu analizè - milisekundėmis išmatuota kiekvieno judesio trukmė (klavišo paspaudimo periodai) slenkant kas judesio periodą ir iš 20 judesiu periodu apskaičiuotas vidurkis ir dispersija (Berškienè ir kt., 2007). Algebrinè dispersijos ir vidurkio išraiška: $\sigma^{2}=\mathrm{a} \mu^{\mathrm{b}}$ (čia a ir b apibrèžia vidurkio ir dispersijos ryšio pobūdi). Gautos skaičiu sekos buvo logaritmuojamos. Pasinaudojus mažiausių kvadratų metodu $\sigma^{2}(\mu)$, gauta priklausomybè buvo aproksimuojama ị tiesę: $\log \left(\sigma^{2}\right)=\mathrm{k} \log (\mu)+1$ (čia $\mu$ - vidurkis, $\sigma^{2}$ - dispersija). Krypties koeficientas vertintas kaip proceso kompleksiškumo matas (Berškienè ir kt., 2007).

Norint išsiaiškinti, kaip suderintai kinta elektrokardiogramos RR ir JT intervalu reikšmès, buvo vertinamas adaptacijos greičio rodiklis (Ad), nusakantis procentini JT ir RR kaitos laipsnio pokyčiu skirtumą krūvio metu (JT - kaip vieno iš aprūpinančiujų organizmo sistemų elemento pokytis, kintant RR elementui - kaip organizmo reguliuojančiujų sistemų elemento pokytis), skaičiuojant pagal formulę: $\mathrm{Ad}=((\mathrm{JTi} / \mathrm{JTo})-$ $(\mathrm{RRi} / \mathrm{RRo})) \times 100 \%$. 


\section{REZULTATAI}

Abieju grupių ŠSD kaita atliekant Rufjè ir 30 s trukmès vertikalių šuoliu fizinio krūvio méginius pavaizduota 1 paveiksle. Esant ramybès būsenai, FKK grupès vidutinès reikšmès $(75,4 \pm 2,1 \mathrm{tv}$. / min) buvo reikšmingai mažesnès negu LFOR (77,5 $\pm 1,3$ tv. / min), ir šis skirtumas buvo statistiškai reikšmingas ( $\mathrm{p}<0,05)$. Po Rufjè fizinio krūvio mėginio buvo užregistruotos tokios maksimalios abiejų tirtų grupių tiriamujų ŠSD reikšmès: FKK $(118,9 \pm 2,6$ tv. / min) daug mažesnès nei LFOR sportininku $(127,5 \pm 1,9$ tv. / min). Šis skirtumas taip pat buvo statistiškai reikšmingas $(\mathrm{p}<0,05)$. Jau antrą atsigavimo minutę po Rufjè mėginio abiejų grupių tiriamujų ŠSD reikšmès buvo panašios (FKK $-81,0 \pm 3,3$ ir LFOR $-83,7 \pm 3,1 \mathrm{tv} . / \mathrm{min})$ ir statistiškai reikšmingai nesiskyrè $(\mathrm{p}>0,05)$. Po antro $30 \mathrm{~s}$ trukmès vertikalių šuolių fizinio krūvio mėginio
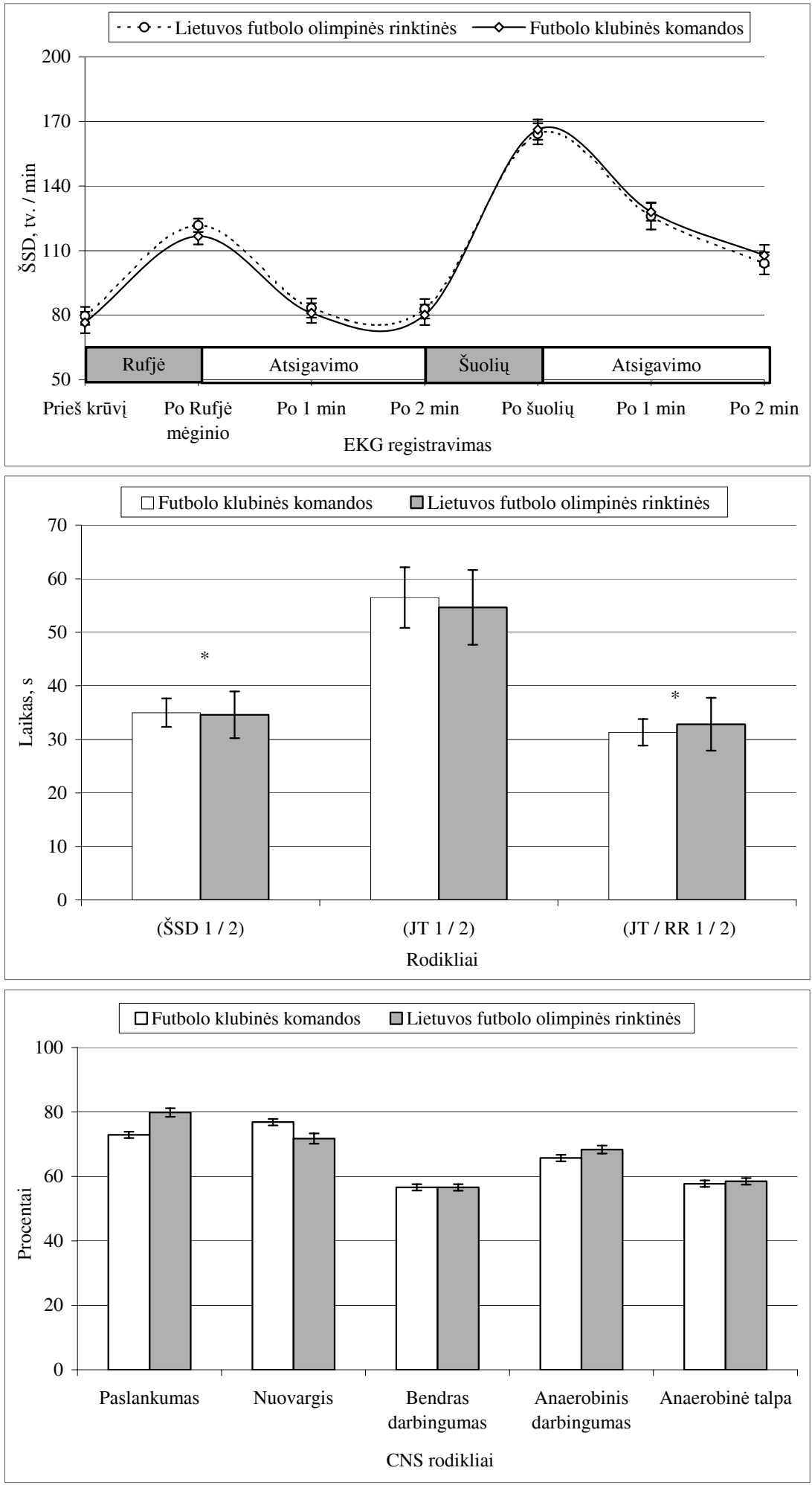

1 pav. ŠSD kaita atliekant fizinio krūvio mèginius

2 pav. EKG rodiklių grižimo ị pradinị lygi pusperiodžio trukmé

Pastaba. * - statistiškai reikšmingas rodikliu skirtumas, $\mathrm{p}<0,05$.

3 pav. Tepingo testu vertinami CNS funkciniai rodikliai 
užregistruotos tirtų grupių ŠSD vidutinès reikšmès buvo panašios, t. y. 164,1-163,6 tv. / min ir statistiškai nesiskyrè $(p>0,05)$. Po šuoliu serijos, pirmą ir antrą atsigavimo minutę, abieju grupių vidutinès ŠSD reikšmès buvo panašios ir statistiškai nesiskyrè.

Lyginant grupių ŠSD pokyčius tiek po Rufjè, tiek po $30 \mathrm{~s}$ trukmès vertikaliu šuoliu fizinio krūvio mèginiu nustatyta, kad po Rufjè mėginio ŠSD padidèjo (FKK - 41,1 $\pm 1,8$, LFOR $42,1 \pm 2,6 \mathrm{tv} . / \mathrm{min})$, o po šuolių atitinkamai $83,5 \pm 2,2$ ir 79,2 $\pm 4,0$ tv. / min. Visgi tiek po pirmo, tiek po antro fizinio krūvio mèginio, lyginant abiejų grupių rodiklius, ŠSD pokyčio vidutinès reikšmès statistiškai nesiskyrè $(\mathrm{p}>0,05)$.

Palyginus abiejų grupių elektrokardiogramos intervalų JT / RR santyki, užregistruotą prieš Rufjè fizinio krūvio mègini ir po jo, nustatyta, kad kaip prieš, taip ir po jo elektrokardiogramos intervalų JT / RR santykio vidutinès reikšmès tarp grupių statistiškai reikšmingai nesiskyrè. Prieš Rufje mègini JT / RR intervalų santykis buvo: FKK $-0,33 \pm 0,01$, LFOR $-0,35 \pm 0,01$, o mèginio pabaigoje buvo užregistruotos beveik tokios pačios vidutinès intervalu reikšmès, atitinkamai $0,44 \pm 0,004$ ir $0,44 \pm 0,006$.

Lyginant adaptacijos greičio rodikli, nusakanti procentini JT ir RR kaitos laipsnio pokyčiu skirtumą Rufjè méginio metu, nustatyta: abieju tirtu grupių šio rodiklio vidutinès reikšmès statistiškai skyrèsi $(\mathrm{p}<0,05)$ ir buvo užregistruotos: FKK $20,2 \pm 1,4$ ir LFOR $-17,3 \pm 1,2 \%$.

Antrame paveiksle pateikta abieju grupių EKG rodiklių grị̌imo i pradini lygi pusperiodžių reikšmès. Nustatyta, kad ŠSD atsigavimo pusperiodžio reikšmė vidutiniškai buvo: FKK grupejje kur kas didesnè $(34,5 \pm 2,6 \mathrm{~s})$ nei LFOR $(27,5 \pm 1,5 \mathrm{~s})$, ir šis skirtumas statistiškai reikšmingas $(p<0,05)$. Elektrokardiogramos JT intervalo rodiklių grižimo i pradini lygi pusperiodžių vidutinè trukmè statistiškai nesiskyrė ir sieke atitinkamai 54,5 $\pm 4,5$ ir $55,3 \pm 3,1 \mathrm{~s}$. Taip pat statistiškai reikšmingas skirtumas $(p<0,05)$ abiejose grupèse buvo nustatytas ir tarp JT / RR santykio grižimo i pradini lygi pusperiodžio trukmę (FKK $-32,1 \pm 2,8$, LFOR $-20,2 \pm 2,0 \mathrm{~s}$ ).

Lyginant CNS funkcinio paslankumo, nuovargio, bendrojo darbingumo, anaerobinio darbingumo ir anaerobinès talpos rodiklius ( 3 pav.) nustatyta, kad LFOR grupeje visi registruoti CNS rodikliai, išskyrus CNS nuovargio, buvo didesni, tačiau šis skirtumas tarp grupių nebuvo statistiškai reikšmingas $(p>0,05)$.
Lyginant duomenų alometrinès analizès metodu tirtu grupių rodiklių ịverčius aptikta, kad šios reikšmès statistiškai patikimai skyrèsi: LFOR $7,8 \pm 0,2, \mathrm{FKK}-6,1 \pm 0,2$.

\section{REZULTATŲ APTARIMAS}

Daug fiziologų, cituodami N. Beršteiną ar kitus tyrèjus, nurodo, kad negalima tiksliai pakartoti nè vieno judesio, kiekvienas yra vis kitoks (Skurvydas, 2003; Avella, Bizzi, 2005; Ting, McKay, 2007). Taigi kyla klausimas, kodèl ịsivaizduojama, kad, pavyzdžiui, ŠKS reakcija i to paties fizinio krūvio mėginius bus identiška ir pasikartos?

Organizmo kompleksiškumas suprantamas kaip jo funkcinių elementų kooperacija, sinerginè sąveika įvairiomis gyvenimo situacijomis sprendžiant iškilusias problemas (Baranger, 2000; Vainoras, 2002). Lygiai taip pat, kaip visumos sužadinti reiškiniai skiriasi nuo tam tikrų pavienių, tokios sinerginès sąveikos būdingos ir žmogaus organizmo veiklai. Bet kurios organizmo funkcinès sistemos veikloje yra daug reguliuojamujuc mechanizmų (aktyvinamujuc ir slopinamujų), kurie veikia ne atskirai kiekvienas sau, o bendrai sinergiškai sąveikaudami. Atliekant ịvairias judejjimo užduotis, skirtingai aktyveja i̇vairių funkciniu sistemu veikla, o reguliuojamujų mechanizmų sąveika rodo jų aktyvumą ir teikia informacija apie sistemos ar viso organizmo funkcinę būklę. Nauji tyrimo rezultatu analizès metodai, nauja tyrimo metodologija išplečia galimybę fiziologams pažinti organizmo funkcijos naujas, ligi šiol neatskleistas ypatybes, panaudoti jas funkcinei būklei vertinti valdant fizinio ir kitokio poveikio trukmę, stiprumą, ieškant optimalių galių ir adaptacijos efekto.

Šis tyrimas išskirtinis, nes iprasti euristiniai metodai pasirode esą netikslūs vertinant santykiškai nedidelius tarpgrupinius skirtumus, tuo tarpu organizmo funkcijos sinergines ypatybes ir jo kompleksiškumą vertinantys metodai leido tai daryti.

Vienas iš tyrimo metu vertinamų rodiklių buvo adaptacijos greičio rodiklis, nusakantis, kaip suderintai kinta elektrokardiogramos RR ir JT intervalu reikšmès atliekant krūvị. Naudojant pasiūlytą vertinimo modeli (Vainoras, 2002) buvo analizuojami reguliavimo ir aprūpinimo sistemu rodikliai. RR intervalo kaita yra intensyvesnè, pirmesnè (pirmiau organizmas paprašo energijos) nei JT intervalo kaita (tuomet intensyvèja metabolizmas). Šis rodiklis abiejose tiriamuju grupèse reikšmingai skyrèsi. Mokslinėse publikacijose nurodyta, kad tokiu būdu apskaičiuojamas adaptacijos greičio rodiklis yra 
labiau susijęs su ilgalaikès adaptacijos ypatybèmis, esminiais funkcinès būklès pokyčiais. Pavyzdžiui, daugelyje publikacijų teigiama, kad prie greitumo krūvių adaptuotų asmenų šio rodiklio reikšmès mažesnès (greitesnè adaptacija) nei prie ištvermès krūvių adaptuotų (Trinkūnas, 2000). Taip pat teigiame, kad dèl didelès apimties krūvių adaptacijos trukmé reikšmingai pailgèja (Poderys ir kt., 2005).

Atsigavimo procese pastebimas laipsniškas funkcinių rodikliu grižimas iki pradinio lygio. Atsigavimo procesas yra pakankamai sudetingas ir lemia daugelio mechanizmų (aktyvinančių ir slopinančiu) aktyvumo kaitą. Visi šie mechanizmai veikia ne atskirai kiekvienas sau, o bendrai sinergiškai sąveikaudami. Šio tyrimo metu užregistruotos mažesnès grižimo i pradini lygi pusperiodžiu trukmès reikšmès didesnio sportinio meistriškumo sportininku grupejje liudija apie ŠKS ir, matyt, viso organizmo reguliavimo mechanizmų optimalesnę sąveiką ir funkcinę būklę.

Alometrinio ryšio sąvoką pirmieji panaudoję mokslininkai (Taylor L. R., Taylor R. A. J., 1977) irode, kad priklausomybè tarp vidurkio ir dispersijos dažniausiai nèra tiesinè, tačiau logaritmuojant ją galima paversti tiesine išraiška. Analizuodami ivairius procesus, L. R. Taylor ir R. A. J. Taylor idejas pradèjo taikyti kiti mokslininkai (Bruce, 2006; Cosma, 2006) ir įrodè, $k a d \sigma^{2}(\mu)$ priklausomybès krypties koeficientą $(\mathrm{k})$ galima sieti su proceso kompleksiškumu (Cosma, 2006). Tepingo testo duomenų sekos alometrinè analizė irodé, kad didelio meistriškumo sportininkams atliekant judejjimo užduotis CNS funkcija buvo kompleksiškesnè. Tai patvirtina kitų autorių teiginius (Viru A. M., Viru M., 2004), kad elito klasès sportininkams igyjant sportinę formą jų treniruotès adaptacinis efektas yra visų reguliacinių mechanizmų suderinamumo didejjimas, t. y. kompleksiškumo padidejjimas.
Šio tyrimo tikslas buvo palyginti funkciniu rodiklių, užregistruotų atliekant fizinio krūvio mėginius, vertinimo metodų tikslumą, kai reikia nustatyti santykiškai nedidelius sportininkų parengtumo skirtumus. Visus taikytus vertinimus galima dalyti į dvi grupes, t. y. iprastus euristinius rodiklių vertinimo metodus ir atskleidžiančius organizmo integralumą bei kompleksiškumą. Gauti tarpgrupiniai palyginimai vienareikšmiškai liudija pastarujų naudai. Turime būti objektyvūs ir pripažinti, kad šio tyrimo metu taikyti kompleksiškumo vertinimo metodai tikrai negarantuoja gautujų optimalumo, o surasti sprendiniai yra optimalūs tik pasirinktų vertinimų ir duotos situacijos atžvilgiu. Pastaraisiais metais sparčiai didèja kompleksiškumą vertinančių metodų kūrimas. Vieni metodai yra tinkami vertinant kompleksiškumą, kiti labiau tinka vertinti kompleksiškumo kaitos ypatybes. Tyrejų siekis kurti vis tobulesnius metodus yra logiškas ir suprantamas, kaip natūralus noras prisidèti iveikiant naujus informatikos, matematikos ir kitoms susijusioms mokslo disciplinoms iškylančius iššūkius (Misevičius ir kt., 2007). Prognozuojama, kad artimiausioje ateityje dėmesys pačiu analizès metodų tyrimui ne mažès, o tik didès.

\section{IŠVADOS}

Šio tyrimo rezultatai patvirtino hipotezę, kad vertinant didelio meistriškumo sportininkų funkcinio parengtumo rezultatus kompleksiškumą vertinantys metodai geriau nei euristiniai atskiru rodiklių vertinimai leidžia atskleisti santykiškai nedidelius tarpgrupinius skirtumus, individualius sportininko meistriškumo pokyčius, todèl jie turètų būti daugiau naudojami atliekant sportininkų tyrimus. Šių metodų kūrimui turi būti skiriama daugiau dèmesio.

\section{LITERATŪRA}

Avella, A., Bizzi, E. (2005). Shared and specific muscle synergies in natural motor behaviors. Proceedings of the National Academy of Sciences of the United States of America,102 (8), 3076-3081.

Baranger, M. (2000). Chaos, Complexity, and Entropy. Cambridge: New England Complex Systems Institute.

Berškiene, K., Sedekerskienė, V., Vainoras, A. ir kt. (2007). RR intervalo vertinimas pagal alometrini ryši. Biomedicinine inžinerija: tarptautinès konferencijos pranešimu medžiaga (pp. 253-256). Kaunas: Technologija.

Bruce, J. W. (2006). Where Medicine Went Wrong. Rediscovering the Path to Complexity. Studies of Nonlinear Phenomena in Life Science, 11. London: World Scientific. P. 337. Cosma, R. S. (2006). Methods and techniques of complex systems science: an overview. In Center for the Study of Complex Systems. Ann Arbor: University of Michigan.

Karoblis, P. (1999). Sporto treniruotès teorija ir didaktika. Vilnius.

Misevičius, A., Blonskis, J., Bukšnaitis, V. (2007). Kombinatorinis optmizavimas ir metaeuristiniai metodai: teoriniai aspektai. Informacijos mokslai, 2, 42-43.

Poderys, J., Buliuolis, A., Poderyte, K., Sadzeviciene, R. (2005). Mobilization of cardiovascular function during the constant-load and all-out exercise tests. Medicina, 41 (12), 1048 - 1053

Raslanas, A., Skernevičius, J. (1998). Sportininku testavimas. Vilnius: LTOK leidykla. 
Skurvydas, A. (2003). Sportininkų rengimo ir tyrimo naujoji metodologija. Sporto mokslas, 1, 2-4.

Šiupšinskas, L. (2004). Fizinio aktyvumo ir sveikatos vertinimai. Kn. Kineziologijos pagrindai. Kaunas. P. 177188.

Taylor, L. R., Taylor, R. A. J. (1977). Aggregation, migration and population mechanics. Nature, 265, 415-421.

Viru, A. M., Viru, M. (2004). The analysis of Peak performance in the physiological aspect. Ugdymas. Küno kultūra. Sportas, 4, 5-9.
Ting, L. H., McKay, J. L. (2007). Neuromechanics of muscle synergies for posture and movement. Current Opinion in Neurobiology, 17 (6), 622-628.

Vainoras, A. (2002). Functional model of human organism reaction to load - evaluation of sportsman training effect. Ugdymas. Küno kultūra. Sportas, 3, 88-93.

Зеленцов, А. М., Лобановский, В. В. (1998). Моделирование трениротовки в футболе. Киев.

\title{
PROBLEM OF ASSESSMENT OF BODY FUNCTIONING OF ELITE ATHLETES
}

\author{
Jonas Poderys, Eugenijus Trinkūnas, Birutė Miseckaitė, \\ Alfonsas Buliuolis, Albinas Grūnovas \\ Lithuanian Academy of Physical Education, Kaunas, Lithuania
}

\begin{abstract}
Human body as a complex dynamic system at onset of exercise responds with series of integrated response and the peculiarities of training and functional state could be recognized by assessing the reactions to exercise test. The problem in sport science is how to perceive very small changes in the functional state of the body during the peak. The aim of this study was to compare the results of assessment of highly skilled athletes obtained by the use of heuristic assessments and by methods providing the information about the integrity or complexity of body functioning.

The participants of the study were two groups of football players, i.e 23 athletes, members of Lithuanian Olympic team, and 23 players from one of the best football clubs in Lithuania. All the participants of the study performed three tests: 1 - finger tapping test of $40 \mathrm{~s}$ duration; 2 - Roufier test (dosed aerobic test); 3 - vertical jumps test of $30 \mathrm{~s}$ duration (maximal anaerobic test). A 12-lead ECG was registered during all exercise tests. The results obtained during the testing were analyzed first, by heuristic methods, and second, by methods designed to reveal synergy and complexity of body functioning. A sequence of movements registered during the finger tapping test was analyzed by methods suggested by the Ukrainian scientists allowing to evaluate features of CNS and the same results of finger tapping test were analyzed by assessing the values of allometic relation. With the purpose of assessing the tuning between the changes of RR and JT intervals of ECG during exercising the index of velocity of adaptation to exercise load was defined $\mathrm{V}_{\mathrm{Ad}}=\left(\mathrm{JT}_{\mathrm{i}} / \mathrm{JT}_{0}\right) 100 \%-\left(\mathrm{RR}_{\mathrm{i}} / \mathrm{RR}_{0}\right) 100 \%$. The peculiarities of recovery after workloads were assessed by evaluating the time of half period of recovery $\left({ }_{1 / 2} \mathrm{~T}\right)$ of registered ECG indices.

The results obtained during the study showed that only methods providing the information about integrity or complexity of body functioning could reveal relatively small differences between two groups of highly skilled athletes more precisely. The attention for developing such methods should be paid in the future.
\end{abstract}

Keywords: exercise test, cardiovascular system, central nervous system. 